\title{
Violência da positividade e educação: da cultura do tédio à promoção da cultura do sentido
}

\section{The violence of positivity and education: from the culture of boredom to the promotion of the culture of meaning}

\section{La violencia de la positividad y educación: de la cultura del tedio hacia la promoción de la cultura del sentido}

\author{
Altair Alberto Fávero' \\ Universidade de Passo Fundo, Professor no Instituto de Filosofia e Ciências Humanas
}

Resumo: Violência é um dos temas recorrentes, não apenas no campo da educação e da filosofia, mas de diversas áreas de estudo, como saúde, antropologia, sociologia, direito, biologia, psicologia, e a lista poderia ser imensa. A violência é algo presente, cotidiano, que invade nossa vida pessoal e coletiva das mais diversas formas. No presente ensaio, tomo emprestado a ideia de violência da positividade do filósofo Byung-Chul Han (2016) para especular sobre violência e educação analisando a tensão entre cultura do tédio e cultura do sentido. $\bigcirc$ escopo do artigo é apresentar, a partir dos estudos de La Taille (2009), Bauman (1998) e Han (2016), algumas reflexões sobre a presença da cultura do tédio no cenário educacional e de que forma tal cultura pode se apresentar como violência da positividade (primeira parte do ensaio); na segunda parte apresento a ideia de cultura do sentido como um indicativo educacional promissor para enfrentar a violência da positividade; por fim, na terceira parte apresento alguns indicativos para enfrentar a cultura do tédio e com isso minimizar os efeitos da violência da positividade.

Palavras-chave: Violência da positividade. Educação. Cultura do tédio. Cultura do sentido.

Abstract: Violence is one of the recurring themes, not only in the field of education and philosophy but in various areas of studies, such as health, anthropology, sociology, law, biology, psychology, being that the list is extensive. Violence is

Pós-Doutor (bolsista Capes) pela Universidad Autónoma del Estado de México; Doutor em Educação pela Universidade Federal do Rio Grande do Sul. 
present in everyday life and invades our personal and collective life in different ways. In the present essay, I take as my axis the idea of the violence of the positivity of the philosopher Byung-Chul Han (2016), to delve into violence and education from the analysis of the tension between the culture of boredom and the culture of meaning. The look of the article is to present, from the studies of La Taille (2009), Bauman (1998) and Han (2016), some reflections about the presence of the culture of boredom in the education scenario, as well as, how this culture can be presented as violence of positivity, this in the first part of the essay; In the second part, I present the idea of culture in the sense of a favorable educational indicator to face the violence of positivity; finally, I mention some indicators to confront the culture of tedium and, in this way, minimize the effects of the violence of positivity.

Keywords: Violence of positivity. Education. Culture of tedium. Culture of meaning.

Resumen: La violencia es uno de los temas recurrentes, no solo en el campo de la educación y de la filosofía sino de diversas áreas de estudios, tales como de la salud, antropología, sociología, derecho, biología, psicología, siendo que el enlistado es extenso. La violencia está presente en el cotidiano e invade nuestra vida personal y colectiva de diferentes formas. En el presente ensayo, tomo como eje la idea de la violencia de la positividad del filósofo ByungChul Han (2016), para adentrar en la violencia y la educación a partir del análisis de la tensión entre la cultura del tedio y la cultura del sentido. La mirada del artículo es presentar, a partir de los estudios de La Taille (2009), Bauman (1998) y Han (2016), algunas reflexiones acerca de la presencia de la cultura del tedio en el escenario de la educación, así como, de qué forma dicha cultura puede presentarse como violencia de la positividad, ello en la primera parte del ensayo; en la segunda parte, presento la idea de la cultura en el sentido de un indicador educacional favorable para afrontar la violencia de la positividad; finalmente, menciono algunos indicadores para afrontar la cultura del tedio y, de ésta manera, minimizar los efectos de la violencia de la positividad.

Palabras clave: Violencia de la positividad. Educación. Cultura del tedio. Cultura del sentido. 


\section{CONSIDERAÇÕES INICIAIS}

Violência é um dos temas recorrentes, não apenas no campo da educação e da filosofia, mas de diversas áreas de estudo, como saúde, antropologia, sociologia, direito, biologia, psicologia, e a lista poderia ser imensa. A violência é algo presente, cotidiano, que invade nossa vida pessoal e coletiva das mais diversas formas. Enquanto fenômeno antropológico, é constitutiva do humano, da forma como nos relacionamos e na construção de nossa própria imagem de pessoa. Pensadores da envergadura de Nietzsche, Freud e Hobbes nos ensinaram que a violência se apresenta como um "constitutivo primordial", pois faz parte do mais íntimo dos impulsos humanos.

Um olhar mais cuidadoso sobre o fenômeno da violência nos ajuda a compreender que ela se distingue da agressividade. Os estudos dos biólogos e etólogos "[...] dizem que o animal que não fosse dotado de um mínimo de agressividade não sobreviveria em nosso mundo" e que "a agressividade básica está na raiz do chamado instinto de sobrevivência, que demove o animal a buscar alimento, água, segurança." (MORAIS, 1995, p. 20). Violência e agressividade, portanto, não são a mesma coisa, pois enquanto esta se apresenta como um dispositivo biológico de sobrevivência, aquela é própria dos seres humanos. Há quase meio século, o filósofo Jean-Marie Domenach e seus colaboradores já ressaltavam em seus estudos que "[...] foi violentamente que o homem dominou a terra e continua a ocupá-la. A vida é violência, o Estado é uma violência organizada, o pensamento é violência." (DOMENACH, 1969, p. 21). O mundo, portanto, não está dividido entre violentos e não violentos, mas entre os que realizam e praticam efetivamente a violência contra os outros e os que tendo consciência de sua condição existencial lutam permanentemente para reduzir a violência a um mínimo possível. Sobre esse aspecto, tem razão Morais (1995, p. 21 ) quando diz que "[...] se nos pusermos em campanhas contra a violência, em nome de uma não-violência fantasiosa, sem que consideremos firmemente a condição paradoxal [do ser humano], pouco alcançaremos além de um moralismo frágil cujos contornos indefinidos derivam da perda da opção dialética da vida." 
Há uma violência velada que precisa ser compreendida na forma como ela se faz presente na própria existência de cada indivíduo e nos múltiplos relacionamentos sociais do cotidiano. No recente ensaio Topología de la violencia o filósofo coreano Byung-Chul Han (2016) faz uma instigante e provocativa análise dos diversos lugares em que a violência se manifesta. Dividido em duas partes, o ensaio de Han descreve as metamorfoses da violência e indica que há uma distinção entre violência da negatividade e violência da positividade. Segundo Han (2016, p. 10), " [...] a sociedade atual evita cada vez mais a negatividade do outro ou do estrangeiro", provocando o desaparecimento gradual das fronteiras e das diferenças. No entanto, "a supressão da negatividade não se pode equiparar com a desaparição da violência, pois junto à violência da negatividade existe também a violência da positividade, que se exercita sem necessidade de inimigos nem de dominação." Esta se faz presente na "massificação do positivo", que se manifesta como excesso de capacidade, excesso de produção, excesso de comunicação, hiperatenção e hiperatividade. "A violência da positividade", ressalta Han (2016, p. 10-1 1), "possivelmente seja mais danosa que a violência da negatividade, pois carece de visibilidade e publicidade, e sua positividade faz com que não haja defesas imunológicas."

No capítulo dedicado à Violência da positividade, Han (2016, p. 137) ressalta que "[...] o desmoronamento da negatividade faz com que surja um excesso de positividade, de promiscuidade generalizada, de consumo, de comunicação, de informação e produção." A massificação do positivo congestiona e obstrui a circulação, causando um infarto no sistema, em que “[...] a informação já não é informativa, a produção já não é produtiva, a comunicação já não é comunicativa."

Valendo-se dos escritos e reflexões de Baudrillard, Han (2016, p. 138) denuncia que "[...] o espaço ascético da positividade, ao ter eliminado o efeito de toda negatividade imunológica do outro, desenvolve novas formas de viralidade, uma nova patologia." Com isso, ele ressalta que a época contemporânea não é mais "uma época viral", pois "[...] as enfermidades principais não são infecções virais ou bacterianas, mas sim são enfermidades psíquicas como o burnout, a hiperatividade ou a depressão, que não se 
remetem a negatividade viral, senão ao excesso de positividade, a violência da positividade." (HAN, 2016, p. 140).

Na violência da positividade não existe um inimigo externo, pois "a falta de negatividade da inimizade faz com que a guerra se dirija contra si mesmo", ou seja, "quem destrói, será destruído"; "quem golpeia, será golpeado"; "quem vence, perde por sua vez." (HAN, 2016, p. 141). Trata-se, portanto, de uma guerra em que nada se pode ganhar, onde não há vencedor. A violência da positividade é "implosiva", diferente da violência da negatividade, que é "explosiva". Enquanto "a violência explosiva exerce uma pressão que vem de fora", a violência implosiva exerce uma pressão de dentro "que causa tensões e impulsos destrutivos"; "o bournout do sujeito de rendimentos é um signo da ameaça de implosão do sistema." (HAN, 2016, p. 142). "A erosão do social cada vez maior", da sociedade contemporânea, acaba produzindo "egos ilhados encerrados em si mesmo." Para Han (2016, p. 144, grifo do autor), “[...] muito mais perigoso que o terror do outro é o terror de si mesmo, o terror da imanência”, pois "[...] já não é possível defender-se com eficácia deste porque já não há negatividade."

\section{QUANDO A CULTURA DO TÉDIO TOMA CONTA DA UIDA}

Não faltam estudos que tentam compreender a cultura do nosso tempo. Cada um, grosso modo, procura traçar características gerais ou específicas que possam esclarecer o modo de se comportar ou de viver de uma determinada geração e, dentre os comportamentos, as manifestações de violência. Para tanto, os estudiosos, inicialmente, utilizam metáforas, não conceitos, para caracterizar as descrições dos fenômenos que estão analisando. $\bigcirc$ trabalho com metáforas possibilita uma compreensão criativa e simbólica daquilo que estamos lidando. A título de exemplo, poderíamos falar da metáfora de "mal-estar", de Sigmund Freud, ou do "império do efêmero", do pensador contemporâneo Gilles Lipovetsky, "medo líquido", do sociólogo 
polonês Zygmunt Bauman, ou, ainda, "violência da negatividade" e violência da positividade, do filósofo coreano Byung-Chul Han.

Em um estudo publicado com o título Formação ética: do tédio ao respeito de si „ o professor e pesquisador do Instituto de Psicologia da USP, Yves de La Taille, faz uma excelente análise de nosso tempo a partir da expressão "cultura do tédio". Na compreensão de La Taille (2009, p. 15), a cultura do tédio se traduz em uma "vida pequena", porque é uma vida sem sentido, sem aprendizagem, sem conhecimento, sem criação, sem projeto, sem fluxo, sem energia, sem potência. La Taille (2009, p. 16) se associa ao grande escritor francês do século XIX, Alfred de Vigny, quando dizia que o tédio é "[...] a grande doença da vida." Mas o que significa vida no tédio? Em que situações experimentamos o tédio? Por que nosso tempo pode ser caracterizado como cultura do tédio? De que forma a cultura do tédio se traduz na "violência da positividade"?

Há uma relação muito próxima e íntima entre o tédio e o tempo. Tempo no tédio é tempo longo, tempo que não passa, tempo que se alonga além da expectativa. Alguém entediado tem a sensação de que os ponteiros do relógio não passam, que o momento é fatigante, que o dia seguinte ou o próximo mês precisam chegar rápidos, na ilusória esperança de que serão melhores que o momento presente. Para La Taille (2009, p. 16), experimentamos o tédio "[...] quando não temos nada para fazer, ou quando estamos fazendo algo que, para nós, carece de significação." Penso que seja exatamente em decorrência dessa "carência de significação" que nosso tempo pode ser caracterizado como a "cultura do tédio". Isso pode soar contraditório, pois, diante de tantos entretenimentos disponíveis, de tantas atividades para nos ocupar, como alguém pode não ter o que fazer?

O problema não reside na falta de ocupação e, sim, na falta de sentido. "Quem diz minha vida é um tédio", esclarece La Taille (2009, p. 17), "[...] está afirmando que ela é morna, insípida, vazia, insuportável, longa demais." Para evitar esse tipo de sensação, muitos buscam ocupar freneticamente seu tempo: lotam sua agenda de atividades, fazem questão de ostentar a plena ocupação de seu tempo, vão às academias, falam ao celular sobre qualquer coisa, verificam incansavelmente seus e-mails a todo instante, navegam exageradamente na internet durante horas, deixam a televisão ligada o tempo todo na esperança 
de encontrar uma novidade com que possam se distrair. Na avaliação de La Taille (2009, p. 17), "[...] engana-se momentaneamente o tédio, mas não se o vence, e o tempo acaba voltando a parecer melancolicamente longo porque a vida permanece pequena." Trata-se da presença implacável da "[...] violência da positividade", caracterizada pelo filósofo coreano Byung-Chul Han (2016) e brevemente apresentada na introdução deste ensaio.

Alguém poderia dizer que esse tipo de análise é exagerada e pouco evidente. Num mundo bombardeado de "felicidade" prometida em cada comercial de televisão, diante de tantas possibilidades de lazer e de consumo, como alguém poderia caracterizar a contemporaneidade como tempo de melancolia ou cultura do tédio? Sentir tédio não seria visto como fraqueza de caráter? Sentir-se infeliz diante de tantas possibilidades não seria visto como incompetência social? Como alguém pode se sentir entediado diante da velocidade estonteante a que somos submetidos todos os dias? Todos esses questionamentos são legítimos e certamente devem ser considerados. No entanto, é preciso tomar cuidado para não simplificar a leitura dos acontecimentos que diariamente vivenciamos. Identificar a presença da cultura do tédio implica vasculhar o que caracteriza a identidade do homem contemporâneo e de que forma ele sucumbe à "violência da positividade".

Em sua obra $\bigcirc$ mal-estar da pós-modernidade, o sociólogo polonês Zygmunt Bauman (1998) alerta para as dimensões da incerteza da identidade de palimpsesto que configura o homem pós-moderno. " $\bigcirc$ mundo pósmoderno", diz Bauman (1998, p. 32), "[...] está se preparando para a vida sob uma condição de incerteza que é permanente e irredutível." No que consiste essa incerteza? Quais os fatores que a possibilitam? De que maneira contribui para a instalação da cultura do tédio? Na análise de Bauman (1998, p. 3336), muitos fatores poderiam ser indicados como provocadores da incerteza: "[...] a nova desordem do mundo", provocada pelo fim das divisões bem definidas que marcaram a política dos blocos de poder do século XX; "[...] a desregulamentação universal", oportunizada pela liberdade concedida ao capital e às finanças à custa de todas as outras liberdades; " [...] o esfacelamento das redes de segurança do estado de bem-estar", que acabou gerando a desigualdade, a qual não consegue mais se autorregular e se autocorrigir; " [...] 
a pragmática consumista", que reduz o outro um mero potencial cliente capaz de adquirir um determinado produto; "a indeterminação e maleabilidade do mundo", produzida pela persuasão eficaz dos meios de comunicação. Nesse mundo de incerteza, reforça Bauman (1998, p. 36), "[...] tudo pode acontecer e tudo pode ser feito, mas nada pode ser feito uma vez por todas - e o que quer que aconteça chega sem se anunciar e vai-se embora sem aviso."

A identidade, neste mundo de incerteza, diz Bauman (1998, p. 36), em vez de ser construída de forma gradual e paciente, é feita por "[...] uma série de 'novos começos', que se experimentam com formas instantaneamente agrupadas, mas facilmente demolidas, pintadas umas sobre as outras: uma identidade de palimpsesto." Nesse tipo de identidade, esquecer é mais importante que memorizar; é mais importante que aprender; é condição para realizar contínuas e promissoras adaptações de novas pessoas ou coisas. $\mathrm{Na}$ identidade de palimpsesto, diz Bauman (1998, p. 36-37), “[...] a própria memória é como uma fita de vídeo, sempre pronta a ser apagada a fim de receber novas imagens, e alardeando uma garantia para toda a vida exclusivamente graças a essa admirável perícia de uma incessante auto-obliteração." Por isso, nessa autoeternizante incerteza, "[...] nenhum emprego é garantido, nenhuma posição é inteiramente segura, nenhuma perícia é de utilidade duradoura, [...] carreiras consideradas sedutoras muito frequentemente se revelam vias suicidas." (BAUMAN, 1998, p. 35). Como construir projetos pessoais de vida num mundo marcado por essa autoeternizante incerteza? Como pensar sobre o que se fará amanhã se o que caracteriza o tempo presente é "uma série de novos começos"? De que forma saber quem se é, se a cada instante somos forçados a novas adaptações, que obrigam a "esquecer" grande parte daquilo que somos ou sabemos?

La Taille (2009, p. 38) dá um destaque especial ao significado do esquecer como condição para esse processo de contínua adaptação: "[...] esquecer é não dar valor, não se fixar em valores". Quando valoramos algo, estão presentes duas formas de mediação: a mediação cognitiva e a mediação afetiva. A mediação cognitiva é responsável por perceber e conceber o mundo, ao passo que a mediação afetiva é que nos leva a "apegarmos" ao mundo, ou seja, a nos interessarmos por ele. Sendo os valores investimentos 
afetivos, ou seja, "[...] mediação afetiva entre o sujeito e o meio natural e social", quando prevalece o império da incerteza, esquecer torna-se indispensável para "desvalorizar" aquilo a que por um tempo tivemos de nos apegar para lhe dar importância. "Viveríamos, por conseguinte", diz La Taille (2009, p. 39), “[...] não em um mundo sem valores, pois a afetividade está inevitavelmente presente e atuante, mas sim em um mundo sem valores estáveis, em um mundo de valores que se equivalem e que se revezam." Neste mundo sem valores estáveis tudo se torna passageiro, trivial, frívolo, efêmero. Pratica-se o “[...] achatamento de valores" e nega-se a hierarquia de valores, pois é malvista a pessoa que "ousa" dizer que certas expressões culturais são melhores do que outras, ou que algumas carecem de valor. "Assim", ressalta La Taille (2009, p. 41), "[...] o refletido, o belo, o raro, o pensamento, construções laboriosos da mente humana, acabam se equivalendo ao espontâneo, ao feio, ao clichê, ao trivial, àquilo, portanto, que não nasce com a intenção de perfeição, mas sim de arroubos momentâneos e efêmeros."

Alguém poderia dizer que deveríamos evitar a hierarquia de valores, pois na história das civilizações, e mesmo no passado recente, o fato de algumas culturas serem consideradas superiores a outras resultou em processos de genocídios, perseguição, barbárie e eliminação de certas culturas. Como não lembrar dos genocídios realizadas pelos europeus quando aportaram na América? Seria insensato apagar da memória a história da escravidão que marcou os processos de colonização da América e da África. As barbáries praticadas no século XX tiveram como pressuposto a hierarquia de valores: a título de exemplo, poderíamos citar as crueldades executadas pelo nazismo em prol da superioridade da "raça ariana", ou as atrocidades praticadas pelos comunistas em nome de "[...] um ideal de organização social". Entretanto, é necessário tomar cuidado para não fazer generalizações apressadas, pois a ausência de hierarquização de valores é muito mais perversa e perigosa que a indicação de certos valores que servirão de indicadores para balizar nossos projetos de vida. Cabe aqui o alerta de La Taille (2009, p. 42) quando diz que “[...] se recusar hierarquia de valores é válido ou prudente em alguns casos, aplicar tal nivelamento para todos os elementos culturais é se privar de balizas para a construção do próprio sentido da vida." 
"Sentido da vida", "projeto de vida" e busca da felicidade têm sido assuntos recorrentes em nosso tempo. Não que sejam temas completamente novos, pois, se vasculharmos a história do pensamento ocidental, certamente encontraremos inúmeros escritos que versam sobre o assunto. Filósofos, místicos, poetas e escritores em geral não pouparam o verbo para abordar a felicidade em seus diversos ângulos. Em nosso tempo o assunto também se mostra com insistência de forma diversificada. Se consultarmos um site de busca na internet ou visitarmos uma livraria, certamente não faltarão indicações de muitos escritos sobre a felicidade. Poderíamos discorrer longamente sobre a qualidade técnica e intelectual de todo esse arsenal bibliográfico que está a nossa disposição. Assim como há bons livros que certamente nos ajudariam a discernir sobre o tema, há outros escritos de qualidade duvidosa, que possivelmente mais alienam do que "jogam luzes" para enfrentar a angustiante problemática.

Na avaliação de La Taille (2009, p. 67) são escritos "[...] cujos autores procuram inescrupulosamente ganhar dinheiro e fama a custa dos infelizes." La Taille está se referindo, de modo específico, aos livros de "autoajuda", que ajudam apenas a quem escreve, pois, "[...] se houvesse um livro de autoajuda que de fato ajudasse, não seria necessário publicar tantos". De qualquer forma, não resta dúvida de que o problema da felicidade é uma preocupação contemporânea e de que, se tal interesse faz parte da agenda de hoje, certamente é porque vivemos "[...] em um clima de mal-estar existencial". Mas o que caracteriza tal mal-estar? Quais são as evidências que possibilitam tal diagnóstico? Que relação existe entre este mal-estar e a cultura do tédio? E por que esse mal-estar poderia ser traduzido em "violência da positividade"?

Na análise de La Taille (2009, p. 67-68, grifo do autor), há dois indícios que retratam o estado insatisfatório com que levamos nossa vida: "[...] a alta incidência da depressão e a alta frequência de suicídios." Não que esses indícios sejam uma característica exclusiva da contemporaneidade. Em outros tempos tais indícios tinham outros nomes (cansaço de viver, melancolia, tristeza, acídia, desespero, pessimismo, nilismo, náusea, desgosto) e representavam um estado existencial específico. Apesar de o termo "depressão" ter sido utilizado desde o século XIX, é nos dias atuais que é "[...] mais empregado e muito presente!" Alguns dados destacados por La Taille (2009, p. 68-70) 
confirmam essa afirmação: conforme a Organização Mundial da Saúde (OMS), há 121 milhões de pessoas diagnosticadas como depressivas, e a depressão é considerada uma das principais causas mundiais de incapacidade para o trabalho; nos Estados Unidos, acredita-se que pelo menos 25 milhões de pessoas ( $10 \%$ da população) tomam ou tomaram algum tipo de antidepressivo; no Brasil, entre 2000 e 2002 houve um aumento de 48\% no consumo de antidepressivos por parte de crianças. Ainda conforme a OMS, no ano 2000 houve 815 mil suicídios, contra 510 mil mortes ocasionadas por crimes e 310 mil por guerras. Conforme o estudo de dois respeitados sociólogos franceses (Cristian Baudelot e Roger Establet), no conjunto do Planeta o suicídio mata em torno de 100 pessoas por hora, e a taxa de suicídios entre jovens de 14 a 25 anos triplicou na segunda metade do século XX. Apesar de os estudos sociológicos sobre o suicídio e a depressão não explicarem tudo, pois há muitas variações que uma análise mais cuidadosa deveria verificar, La Taille (2009, p. 10) sentencia: "Uma coisa é certa: seja qual forem as diversas causas, tal ato de desespero quase sempre traduz o fato de que a vida perdeu o sentido. [...] o suicídio é o infeliz final de um longo processo de perda do sentido." Talvez poderíamos inferir que a presença da "violência da positividade" se traduz na forma como alguns dão cabo de sua própria vida, mas isso seria tema para um outro ensaio.

Na leitura de La Taille (2009, p. 71), com a qual concordo, há uma íntima ligação entre o estado insatisfatório que provoca a depressão e o suicídio e a cultura do tédio que se instaurou na cultura contemporânea. Em seu escrito Filosofia do tédio, o filósofo norueguês Lars Fr. H. Svendsen (2006) tipifica dois tipos de tédio: o tédio situacional ou superficial e o tédio existencial ou profundo. $O$ primeiro diz respeito a situações passageiras que todos nós, em maior ou menor proporção, enfrentamos no dia a dia; o segundo, a uma maneira de "viver a vida" e está intimamente ligado "à perda de sentido". Isso nos faz lembrar uma consideração importante feita por Charles Taylor (1997. p. 33) em seu livro As fontes da construção do self, quando diz que "[...] o problema do sentido da vida está em nossa agenda, por mais que possamos zombar dessa expressão, quer na forma de uma perda ameaçada de sentido, quer porque o encontro do sentido para nossa vida é o objeto de uma busca." Segundo Taylor (1997, p. 34), o problema do sentido da vida não se colocava 
para os pré-modernos, pois eles tinham convicção de que havia um sentido da vida e o desafio se limitava a encontrar o caminho certo para a sua execução. De forma diferente, nós nos defrontamos com "a falta de sentido", com o medo "[...] de um vazio aterrorizante, com uma espécie de vertigem, ou mesmo uma fratura do nosso mundo e do nosso corpo-espaço." É a presença marcante da "violência da positividade" que se faz sentir no vazio existencial. É por isso que o medo do vazio, ou o tédio existencial, é decorrente da carência de sentido e "[...] encontrar um sentido para a vida depende de construir expressões significativas adequadas." (TAYLOR, 1997, p. 33).

Vencer a cultura do tédio pode se apresentar como uma alternativa confiável para superar o conjunto de problemas que assolam nossa contemporaneidade, inclusive da violência escolar, da violência da positividade e das violências invisíveis que tomam conta do cotidiano. $\bigcirc$ excesso de consumo, a barbárie que se materializa de diversas maneiras, o empobrecimento cultural que tomou conta de nossos educandários, a ostentação de futilidades, dentre outras tantas manifestações, são apenas alguns dos traços da cultura do tédio e da violência da positividade que se instaurou nas nossas vidas. La Taille sugere que uma das formas de superar a cultura do tédio ocorre pela instauração da cultura do sentido. É essa direção que abordarei na próxima seção.

\section{PROMOUENDO UMA CULTURA DO SENTIDO}

A palavra "sentido" remete a muitos significados. Se formos ao Novo Dicionário Aurélio de Língua Portuguesa, encontraremos 18 significações que o termo carrega em nosso idioma. Não nos interessa aqui analisar cada uma delas. No entanto, gostaria de abordar brevemente dois aspectos existenciais complementares que se tornam decisivos na abordagem que estou fazendo: trata-se dos termos "direção" e "significação". ○ conceito de direção está associado à ideia de rumo, de indicativo, de lugar futuro. Se pergunto "em que sentido devo seguir?" estou me referindo à ideia de direção, projeção, intencionalidade. Certamente, é essa "falta de sentido de direção" que tomou 
conta da vida de quem está imerso na cultura do tédio. O outro sentido existencial diz respeito à significação. "Uma vida com sentido é uma vida significativa [...]", diz La Taille (2009, p. 75), e é significativa porque está ancorada em valores, escolhas, metas. A ausência de valores e escolhas, ou mesmo quando temos valores que inflacionam e desinflacionam constantemente, a vida tornase entediante, e, com isso, há perda de sentido. $\bigcirc$ que fazer diante de uma vida contaminada pela cultura do tédio? É possível, educacionalmente, criar estratégias para vencer a cultura do tédio?

Para La Taille (2009, p. 79), “[...] somente uma cultura do sentido pode vencer uma cultura do tédio", mas para que tal cultura se estabeleça são necessárias duas condições: i) que o sujeito se veja imerso num contexto problemático; ii) que estejam ao alcance do sujeito elementos que possam alimentar a construção de novas soluções. Concordo com La Taille que ambas as condições estão presentes no contexto atual e é sobre elas que a educação, de forma mais ampla, e a escola, de forma mais específica, ocupam um lugar de destaque.

A educação é considerada por La Taille a "atividade incontornável" para que se torne realidade a construção de uma cultura do sentido, e a escola pode ser "[...] uma verdadeira usina de sentidos" se conseguir promover espaços de convivência e de cidadania compatíveis com a cultura do sentido. Contudo, para que isso aconteça é necessário que os responsáveis de ambas (educação e escola) sejam capazes de executar tarefas imprescindíveis para a promoção da cultura do sentido. Quem seriam esses responsáveis e quais seriam essas tarefas? Para La Taille, os responsáveis pela educação e pela escola são os adultos (pais, professores, lideranças, diretores, coordenadores), e uma das primeiras tarefas é cuidar do mundo.

Ao analisarem a tese de que estamos deixando para nossas futuras gerações uma sociedade e um planeta em péssimas condições, os franceses Denis Jeambar e Jacqueline Rémy (2006), em seu livro Nossos filhos nos odiarão, sentenciaram nosso tempo da seguinte maneira: "Uma sociedade que não cuida de seu futuro é uma sociedade que não ama seus filhos." Ancorado nas considerações dos escritores franceses, La Taille (2009, p. 82-84) analisa a contradição dos que hoje comandam o Planeta: "Quando jovens, os adultos que hoje têm entre 45 a 65 anos, contestaram o conformismo de seus pais 
[...]", criticaram a sociedade individualista, consumista e autoritária que os tornavam vítimas; quando esses jovens cresceram, "ocuparam seu lugar no mundo do trabalho, criaram famílias, desenharam contornos de convivência, se alimentaram do planeta e dirigiram a educação."

A contradição reside na ação diametralmente oposta aos ideais que pregavam 40 anos atrás: de contestadores do egoísmo e individualismo construíram uma sociedade hiperindividualista e de relações sociais fragmentadas; de críticos à sociedade do consumo, produziram uma verdadeira bulimia de consumo; de proclamadores da paz e do amor, elegeram a agressão e a violência como características normais de convivência; de zombadores da segurança dos seus pais, vivem hoje na fantasiosa segurança dos condomínios fechados e das companhias de seguros; exigiram a valorização dos jovens e inventaram o culto da juventude, mas hoje descuidam da educação, direito fundamental para uma juventude autêntica. Penso que mais uma vez são apropriadas as palavras dos escritores franceses Denis Jeambar e Jacqueline Rémy (2006, p. 8) quando dizem:

Tivemos todos os trunfos na mão, exercemos sem piedade nosso direito de inventário sobre os valores que as gerações anteriores nos haviam transmitido, crescemos em uma sociedade em plena expansão econômica. E que futuro preparamos para nossos filhos? Somos a primeira geração que legará à próxima menos do que recebeu da anterior. (JEAMBAR; REMY apud LA TAILLE, 2009, p. 84).

$\bigcirc$ que deu errado? Qual foi o caminho torto que escolhemos para chegar a essa situação que tanto nos amedronta? Como promover uma cultura do sentido diante de uma realidade que está se tornando pesadelo? Para La Taille (2009, p. 86), “[...] não há 'cultura do sentido' sem educação para o sentido." Para que isso aconteça é necessário reabilitar a verdade; dar crédito à autêntica política; denunciar a falsidade dos apelos publicitários; desmascarar a perversidade dos falsos ídolos; ser mais precavido diante do entusiasmo ingênuo que muitos têm em relação aos meios tecnológicos; ser mais cuidadoso com os julgamentos precipitados e, por isso, preconceituosos; recolocar o conhecimento como âncora essencial do ato educativo; e possibilitar "[...] às novas gerações 
uma bagagem intelectual sólida." (LA TAILLE, 2009, p. 101). Para cada um desses indicativos seria necessária uma longa e cuidadosa explanação. Não farei isso neste espaço, até porque La Taille realiza uma esmerada análise em seu competente escrito referido no presente ensaio. Na próxima seção apresento alguns elementos que sejam indicadores de ações de cultura da não violência a fim de combater a cultura do tédio e promover a cultura do sentido.

\section{CONSIDERAÇÕES FINAIS: PROMOUENDO A CULTURA DO SENTIDO}

Nesta última parte do ensaio concentrarei minhas reflexões a fim de apontar alguns indicativos que possam contribuir para enfrentar a cultura do tédio e promover a cultura do sentido. Compreendo esse enfrentamento como uma forma de minimizar a violência da positividade que se faz presente como uma "microfísica da violência" para usar as expressões do filósofo coreano Byung-Chul Han (2016), já mencionado na introdução do presente ensaio.

$\bigcirc$ enfrentamento da cultura do tédio não ocorre como um ato isolado, desconectado de um conjunto de ações que devem acontecer organicamente no processo formativo dos que compartilham o espaço escolar. Seria ingenuidade pensar que a simples introdução de atividades isoladas no cotidiano escolar seria suficiente para superar a cultura do tédio, neutralizar a "violência da positividade" e instaurar a cultura do sentido. No entanto, a identificação da violência da positividade e a reflexão sobre a cultura do tédio inserida como exercício pedagógico permanente, com professores altamente capacitados e comprometidos em promover e implantar a "cultura do sentido", poderá se tornar um importante veículo para enfrentar os dilemas educacionais da contemporaneidade. Em que aspectos a reflexão sobre a cultura do tédio e a identificação da violência da positividade poderão contribuir para instaurar a cultura do sentido? Indicaremos alguns elementos que poderão ser explorados nessa direção:

a) fornecer ferramentas intelectuais para examinar a vida: é do conhecimento de todos nós o famoso pronunciamento de 
Sócrates em sua defesa, diante do tribunal hostil de Atenas, ao dizer aos seus acusadores, "[...] que vida sem exame não é vida digna de um ser humano." (SÓCRATES, 1985, p. 22). Nada mais apropriado para pensar a presença da cultura do sentido como algo indispensável no processo formativo. $\bigcirc$ apelo de Sócrates feito há mais de 25 séculos se reatualiza num cenário marcado pela não reflexão, pelo excesso de consumo, pela "vida pequena" que tomou conta da sociedade atual. Ausência de reflexão se traduz em violência da positividade que toma conta da vida. A promoção da Cultura do Sentido pode se tornar potencialmente produtiva para fornecer ferramentas intelectuais que sejam capazes de enfrentar a cultura do tédio. Como diz La Taille (2009, p. 101), "[...] de nada adianta ser capaz de raciocinar bem, mas não possuir conhecimentos que alimentam a reflexão. Mas tampouco adianta possuí-los sem ser capaz de organizá-los de forma a chegar a diversas conclusões." Dito de outro modo, pensar uma cultura do sentido nos processos formativos que tenha por objetivo superar a cultura do tédio implica articular competentemente conteúdo e método. ${ }^{2}$

b) criar espaços para a prática de virtudes que possibilitem a construção de significações para a vida: La Taille (2009, p. 106) indica que algumas virtudes são essenciais e devem ser cultivadas para que ocorra a construção de significações para a vida. A boa-fé, por exemplo, é uma virtude moral, pois corresponde, no dizer do filósofo francês André Comte-Sponville (1995, p. 259), a "[...] amar a verdade mais que a si mesmo." Uma pessoa de boa-fé é aquela que não mente e se sente desconfortável se aquilo que está dizendo não está de acordo com a verdade. É

\footnotetext{
2 No capítulo 3 do livro Educar o educador, Fávero e Tonieto (2010, p. 49-54) analisam como se realiza a relação entre conteúdo e método na formação de professores e avaliam como tal relação influencia de forma direta o trabalho desenvolvido pelos professores no exercício profissional da docência. Eles defendem a tese de que o modo como se compreende a relação entre conteúdo e método determina o modo como são pensados os cursos de formação de professores e o modo como o professor organiza sua prática pedagógica.
} 
por isso que, para La Taille (2009, p. 107), “[...] a boa-fé é virtude incontornável para a construção de uma 'cultura do sentido'." Como já dizia Aristóteles, as virtudes não são talentos inatos ou traços que herdamos geneticamente. No dizer de La Taille (2009, p. 101, grifo do autor), “[...] virtudes são qualidades de caráter decorrentes de um trabalho de autoaperfeiçoamento [...]" e estão "[...] ao alcance de cada um, contanto que os esforços necessários sejam envidados." Acreditamos que a prática da Cultura do Sentido possibilita que o processo formativo seja um espaço de experiência da boa-fé, e a escola, um lugar para a prática da virtude e para o enfrentamento da violência da positividade.

c) o tempo como fluxo de direção e sentido à vida: com frequência escutamos a famosa máxima "tempo é dinheiro", que marcou não só a sociedade moderna do capitalismo industrial, mas também nosso estilo de vida. Vivemos o tempo cronometrado, o tempo calculado em dinheiro, o tempo escasso, o tempo negociado, a vida sem tempo. É essa "vida sem tempo" que hoje está em crise. Em seu livro A crise do século XX, Gilberto de Mello Kujawski (1988) diz que a crise que vivemos hoje não é algo distante e abstrato, identificável apenas com herméticas especulações filosóficas, mas se manifesta nas situações de desconforto que ocupam o mais prosaico cotidiano. Nas palavras de Han (2016, p. 1 12), trata-se da microfísica da violência que "[...] destrói toda a possibilidade de ação e atividade. Suas vítimas são jogadas em uma passividade radical. A destrutividade da violência microfísica, tem sua origem no excesso de atividade que se manifesta como hiperatividade." $O$ excesso de tudo gera a crise de sentido e a violência da positividade. De acordo com Kujawski (1988, p. 54), “[...] a compreensão da crise do século XX tem que começar por onde nós vivemos, na deterioração do cotidiano [...]" Podemos dizer que uma das crises do nosso cotidiano é a deterioração do fluxo do tempo. Em resumo, diz La Taille (2009, p. 1 15), “[...] cortamos o tempo em fatias, e nosso presente não se liga ao nosso 
passado e tampouco a nosso futuro." Em outras palavras, "vivemos no eterno presente", "estancamos simbolicamente o fluxo do tempo" e, com isso, "penamos em atribuir sentido à vida". Pensar sobre o tempo, identificar os motivos da eternização do tempo, compreender a crise do tempo que produz a cultura do tédio pode se tornar objeto de investigação para um bom exercício da constituição da cultura do sentido.

d) tornar o tempo de formação um espaço de apropriação dos valores culturais: não precisamos fazer grandes estudos para constatar que nosso modelo societário é essencialmente tecnocrata, esquecido, ou simplesmente desinteressado, de grande parte dos valores que foram decisivos na constituição de nossa civilização. Foram esses valores que constituíram a base dos conhecimentos necessários à ideia que se tinha então do que deveria ser a cultura. No entanto, apesar de tantas conquistas, inovações e invenções produzidas, vivemos hoje à deriva de "[...] um mundo saído dos seus eixos [...]" (HERMENAU, 2003, p. 84).3 No Brasil, nunca tivemos tantas crianças e jovens na escola; no entanto, estamos dramaticamente mergulhados numa cultura do tédio, que produz evasão escolar, violência, reprovação, patologias, mal-estar docente, estresse, depressão, ansiedade, apatia e embrutecimento cultural. Tornar o tempo escolar um espaço de apropriação dos valores culturais significa fazer da escola um lugar onde as crianças e os jovens possam compor sua bagagem intelectual, ou seja, apropriar-se daquilo que a humanidade produziu ao longo dos séculos. Trata-se de um processo de conhecimento dos grandes autores, das grandes obras, das grandes invenções e das grandes descobertas que possibilitam ver o processo evolutivo da sociedade. Não se trata de fazer uma veneração ingênua do passado, mas de auxiliar

\footnotetext{
3 Tomamos emprestado essa expressão do título de um texto escrito pelo professor Frank Hermenau (2003), que trata sobre a relação entre política e educação em Immanuel Kant e Hannah Arendt. O texto foi publicado no livro Filosofia prática e pedagogia, organizado pelo professor Claudio Dalbosco.
} 
crianças e jovens a perceberem que há muito mais elementos positivos na história da cultura do que traços destrutivos.

e) La Taille (2009, p. 121-127, grifo do autor) indica três razões que justificam a ideia de que os alunos devem na escola "[...] compor sua bagagem intelectual dando lugar de destaque àquilo de mais rico que a humanidade criou": i) tornar a memória do passado uma referência importante para perceber o fluxo do tempo; ii) prestar uma homenagem à humanidade; e iii) explicitar a admiração, no sentido de espanto que gera curiosidade e superação. Penso que as três razões indicadas por La Taille estão plenamente relacionadas com o desafio de tornar o saber escolar algo importante e necessário para promover a cultura do sentido. Se hoje temos crianças e jovens que desdenham a escola, que julgam desnecessário se apropriar dos fundamentos culturais que constituíram nossa civilização, isso se deve, em grande parte, a terem sido contaminados com a cultura do tédio e da violência da positividade que tomou conta, inclusive, do ambiente escolar. $\bigcirc$ antídoto para combater esse vírus do tédio e a violência da positividade passa pela instauração do sentido, que é alimentado pela curiosidade e pelo espírito de superação. Penso que a formação de uma cultura do sentido pode ser promissora nessa direção, na medida em que desperta nos estudantes a dimensão problematizadora dos acontecimentos, promove o diálogo investigador e torna o processo de formação um exercício reflexivo sobre a própria vida e a cultura que nos constituiu.

f) fazer da educação um processo que dá sentido à vida: em seu belo livro Ética para meu filho, o filósofo e educador espanhol Fenando Savater (2002, p. 97), ao se dirigir ao próprio filho e, por extensão, a todos os jovens do mundo, afirma que a única obrigação que temos nesta vida é "não sermos imbecis". O próprio Savater esclarece, etimologicamente, que a palavra imbecil significa "bastão", "bengala", ou seja, "o imbecil é aquele que precisa de bengala para caminhar." Tanto a "bengala" quanto 
"o caminhar" estão sendo usados no sentido metafórico, ou seja, "[...] o imbecil não é manco dos pés, mas do pensamento."

Savater (2002, p. 97-98) diz que há vários modelos de imbecis: a) "o que acredita que não quer nada" e que para ele "tudo dá na mesma", por isso boceja frequentemente e vive eternamente cochilando, mesmo estando de "olhos bem abertos"; b) "o que acredita que quer tudo" o que aparece na sua frente e, por isso, agarra coisas opostas sem se dar conta de que existe diferença entre elas; c) "o que não sabe o que quer nem se dá o trabalho de averiguar", por isso é "conformista sem reflexão" ou "rebelde sem causa"; d) o que sabe que quer e, mais ou menos, sabe porque o quer, mas quer frouxamente, com medo ou com pouca força; e) "o que quer com força e ferocidade, de maneira bárbara", mas tem pouca sensibilidade em relação à realidade que vive e, por isso, confunde "vida boa com aquilo que o excita."

Para Savater (2002, p. 99), todas as formas de imbecilidade terminam mal, no sentido de que os imbecis "[...] acabam prejudicando a si mesmos e nunca conseguem viver a vida boa." Penso que a caracterização da imbecilidade feita por Savater é oportuna para diagnosticar os traços da cultura do tédio que tomou conta da vida do nosso tempo, inclusive no ambiente escolar. Combater a imbecilidade é, certamente, um bom caminho para promover a cultura do sentido. É nesse aspecto que um dos nossos grandes desafios como educadores é fazer da educação um processo que dá sentido à vida, a fim de impedir que a imbecilidade tome conta do mundo, inclusive da escola.

Os elementos indicativos para promover a formação da cultura do sentido não se encerram aqui. Haveria mais de uma centena de elementos que poderiam ser exaustivamente considerados. Elencamos apenas cinco com a finalidade de indicar ações pragmáticas no contexto escolar para o combate à cultura do tédio e promoção da cultura do sentido. Resta saber se, como educadores, temos coragem, persistência, formação e clareza para implementá-las nas nossas práticas pedagógicas. 


\section{REFERÊNCIAS}

BAUMAN, Z. O mal-estar da pós-modernidade. Tradução Mauro Gama e Cláudia Martinelli Gama. Rio de Janeiro: Zahar, 1998.

COMTE-SPONVILLE, A. Tratado das pequenas virtudes. São Paulo: Martins Fontes, 1995.

DOMENACH, J. M. et al. A violência. Rio de Janeiro: Laudes, 1969.

FÁVERO, A. A.; TONIETO, C. Educar o educador: reflexões sobre formação docente. Campinas: Mercado de Letras, 2010.

HAN, B.-C. Topología de la violencia. Barcelona: Herder, 2016.

HERMENAU, F. No fundo, educamos desde sempre para um mundo saído de seus eixos: sobre a relação entre Política e educação em Immanuel Kant e Hannah Arendt. In: DALBOSCO, C. (Org.). Filosofia prática e pedagogia. Passo Fundo: Ed. UPF, 2003. p. 84-93.

JEAMBER, D.; RÉMY, J. Nos enfants nous haïront. Paris: Seuil, 2006.

KUJAWSKI, G. de M. A crise do século XX. São Paulo: Ática, 1988.

LA TAILLE, Y. de. Formação ética: do tédio ao respeito de si. Porto Alegre: Artmed, 2009.

MORAIS, R. de. Violência e educação. Campinas: Papirus, 1995.

SAVATER, F. Ética para meu filho. Tradução Monica Stahel. São Paulo: Martins Fontes, 2002.

SÓCRATES. Defesa de Sócrates. Tradução Jaime Bruna. São Paulo: Abril Cultural, 1985.

SVENDSEN, L. R. H. Filosofia do tédio. Rio de Janeiro: Tusquets Editores, 2006.

TAYLOR, C. As fontes do self: a construção da identidade moderna. Tradução Adil Ubirajara Sobral e Dinah de Abreu Azevedo. São Paulo: Loyola, 1997.

Recebido em:: 16 de março de 2018 Aceito em:: 21 de junho de 2018

Endereço para correspondência: Rua São José, caixa postal 61 1, 99001-970, Passo Fundo, Rio Grande do Sul, Brasil; altairfavero@gmail.com 
